\title{
Externí anuloplastický prstenec a remodelace kořene aorty - nové, fyziologické řešení výdutí kořene aorty a nedomykavosti aortální chlopně: naše první zkušenost
}

\author{
Jaroslav Hlubocký1, Kateřina Jirátová2, Kateřina Plocová1, Miroslav Špaček', Vladimír Vondráček1, \\ Jan Kacvinskýs , Jaroslav Lindner ${ }^{1}$ \\ 'Il. chirurgická klinika - kardiovaskulární chirurgie, 1. lékařská fakulta Univerzity Karlovy a Všeobecná fakultní nemocnice, Praha \\ 2II. interní klinika kardiologie a angiologie, 1. lékařská fakulta Univerzity Karlovy a Všeobecná fakultní nemocnice, Praha \\ ${ }^{3}$ Anatomický ústav, 1. lékařská fakulta Univerzity Karlovy, Praha, Česká republika
}

Adresa: MUDr. Jaroslav Hlubocký, II. chirurgická klinika - kardiovaskulární chirurgie, 1. LF UK a VFN, U Nemocnice 2, 12800 Praha 2, e-mail: jaroslav.hlubocky@vfn.cz

Záchovné operace na aortální chlopni patří k výkonům, které pacientům přinášejí nesporné výhody, jsou ale technicky podstatně náročnější než náhrada chlopně protézou. Aicher a spol. demonstrovali, že počet komplikací souvisejících s výkonem na chlopni se při záchovných operacích aortální chlopně v patnáctiletém sledování pohybuje kolem $12 \%,{ }^{1}$ zatímco riziko komplikací u nemocných po náhradě aortální chlopně je za stejnou dobu vyšší než $60 \%{ }^{2}$

Existují dva základní typy záchovných operací aortálního kořene - remodelace aotálního kořene podle Yacouba $^{3}$ a reimplantace aortální chlopně podle Davida. ${ }^{4}$ Zatímco u Yacoubovy operace jsou protézou nahrazeny aortální sinusy, sinotubulární junkce a část ascendentní aorty, u Davidovy operace je aortální chlopeň zevnitř všita do protézy, která jí tak vytváŕí oporu.

Remodelaci kořene aorty podle Yacouba bývá oprávněně vyčítáno, že nekoriguje dilataci aorto-ventrikulární junkce. Proto bývá většina pacientů s aortoanulární ektazií a výdutí kořene aorty operována technikou reimplantace aortální chlopně podle Davida. Technika reimplantace aortální anulus stabilizuje, ale vystavuje cípy aortální chlopně většímu namáhání. ${ }^{5}$

Nová technika kombinuje remodelaci aortálního kořene s implantací zevního anuloplastického prstence Coroneo, který stabilizuje a/nebo redukuje velikost aortálního anulu a zachovává přitom jeho elasticitu. ${ }^{6,7}$ Takový přístup se zdá být vhodným řešením u pacientů $s$ insuficiencí aortální chlopně a s dilatací kořene aorty. Výhody remodelace kořene aorty jsou přitom zachovány. Výkon na aortálním kořeni, je-li indikován, je velkou výhodou u pacientů s bikuspidální aortální chlopní, protože umožňuje korigovat postavení komisur tak, aby se výsledný úhel, který svírají, co nejvíce blížil $180^{\circ}$.
Fixace prstence se provádí pěti stehy s podložkami, které jsou naloženy pod aortální chlopní zevnitř a uzleny zevně (obrázek 1). Jsou umístěny pod středem každého cípu a v komisurách v jedné rovině, s výjimkou pravo-nekoronární komisury, kde není steh založen z obavy o převodní systém. Remodelace se provádí standardním způsobem: protézou, na které jsou vystřiženy „jazyky“ neosinusů (obrázek 2). Po provedení remodelace je implantován

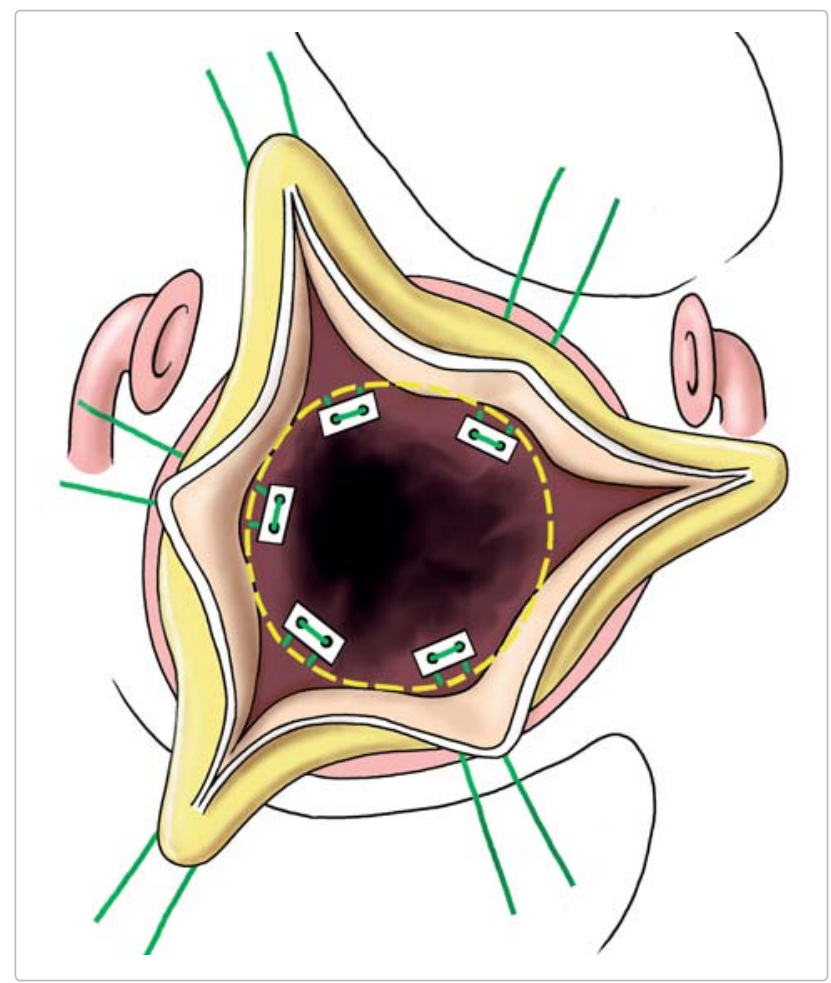

Obrázek 1 Způsob nakládání stehu pro prstenec 
prstenec (obrázek 2 a 3), nakonec jsou našity anastomózy koronárních tepen (obrázek 4).

Od dubna 2010 do ledna 2011 jsme na našem pracovišti operovali touto technikou pět pacientů. Tři pacienti měli trikuspidální, dva bikuspidální aortální chlopeň. U všech byla použita technika remodelace kořene, korekce prolapsu cípů s jejich centrální plikací a implantace zevního aortálního prstence. U jednoho pacienta s bikuspidální aortální chlopní byla provedena resekce kalcifikovaného raphe s následnou suturou. Průměrný stupeň aortální regurgitace byl př̀edoperačně $3,6(3-4)$, při propuštění $0,4(0-1)$. Průměrný maximální gradient na aortální chlopni $\mathrm{v}$ den propuštění byl 10,6 mm Hg.

Časné výsledky této techniky jsou slibné. Velkou výhodou je reprodukovatelnost a standardizace celé operace. Tato technika je použitelná jak pro trojcípou, tak pro dvojcípou aortální chlopeň. Ve druhém případě (u dvojcípé chlopně) navíc umožňuje repozici komisur do výhodnějšího postavení. Na dlouhodobé potvrzení výhod této techniky musíme vyčkat výsledků zpracovávaných

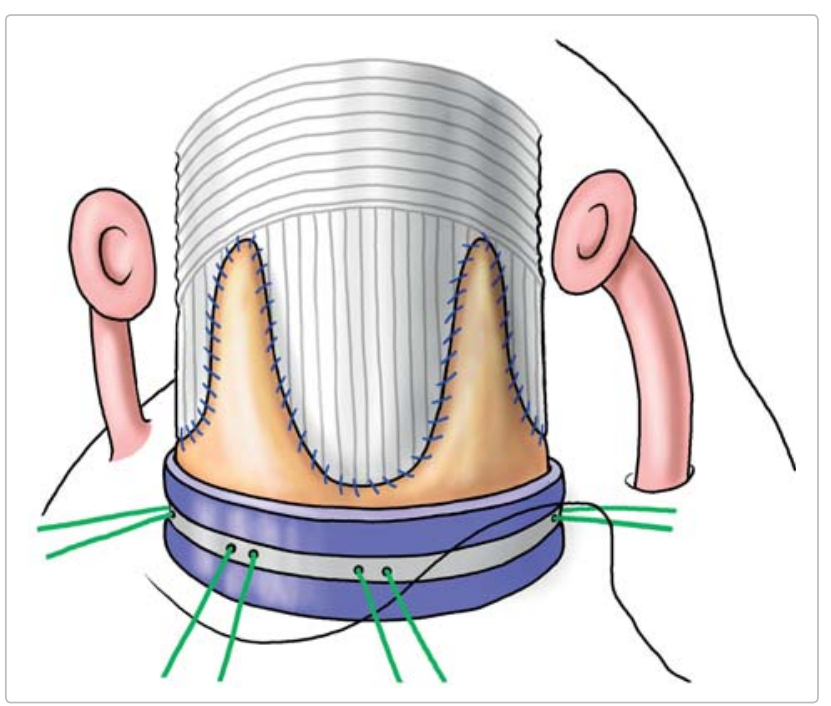

Obrázek 2 Schéma postupu operace

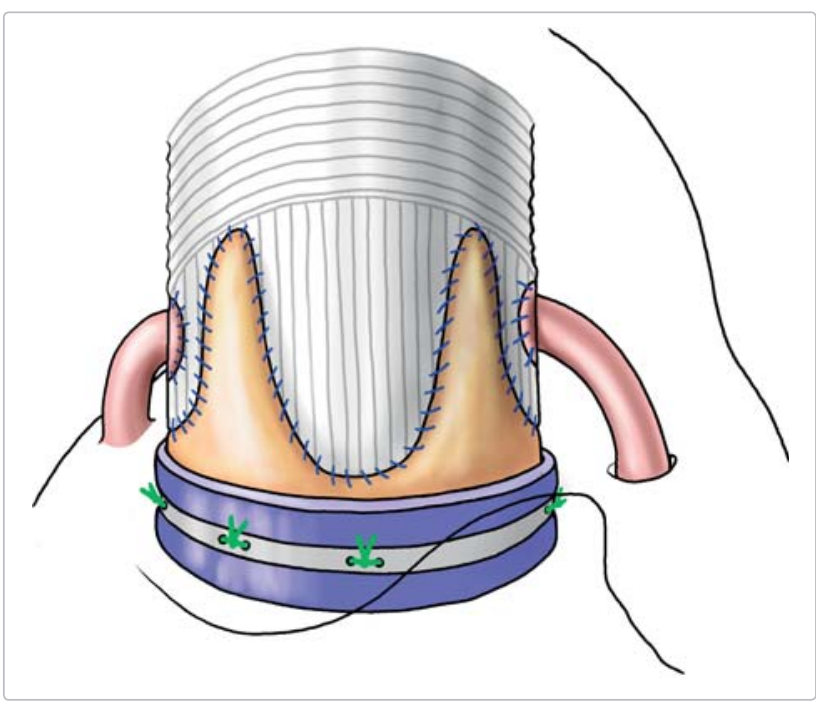

Obrázek 3 Umístění prstence po dokončení remodelace

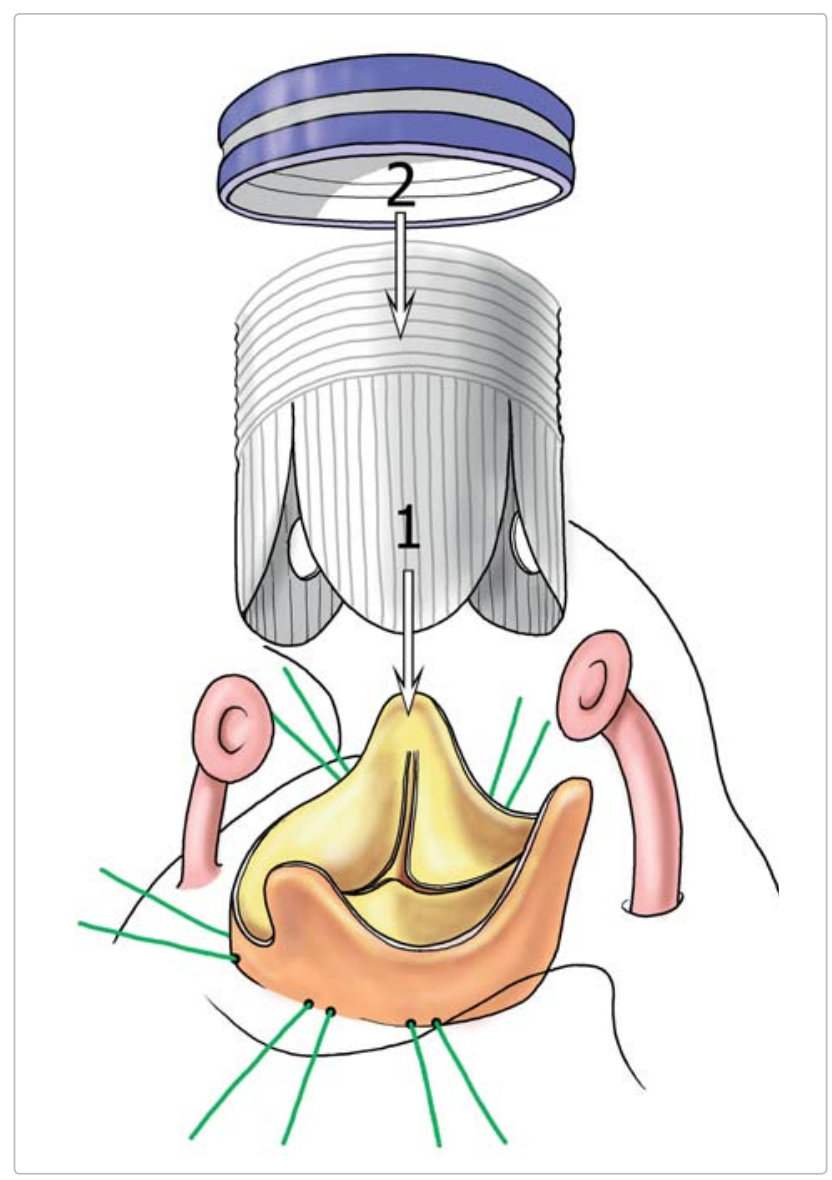

Obrázek 4 Konečný stav po implataci koronárních tepen

mezinárodním registrem CAVIAAR (Conservative Aortic Valve Surgery for Aortic Insufficiency and Aneurysm of the Aortic Root), na kterém se podílí i naše pracoviště.

\section{Literatura}

1. Aicher D, Fries R, Rodionycheva $S$, et al. Aortic valve repair leads to a low incidence of valve-related complications. Eur J Cardiothorac Surg 2010;37:127-132.

2. Hammermeister K, Sethi GK, Henderson WG, et al. Outcomes 15 years after valve replacement with a mechanical versus a bioprosthetic valve: final report of the Veterans Affairs randomized trial. J Am Coll Cardiol 2000;36:1152-1158.

3. Yacoub MH, Gehle P, Chandrasekaran V, et al. Late results of a valve-preserving operation in patients with aneurysms of the ascending aorta and root. J Thorac Cardiovasc Surg 1998;115:1080-1090.

4. David TE, Feindel CM. An aortic valve-sparing operation for patients with aortic incompetence and aneurysm of the ascending aorta. J Thorac Cardiovasc Surg 1992;103:617-621; discussion 622.

5. Fries R, Graeter T, Aicher D, et al. In vitro comparison of aortic valve movement after valve-preserving aortic replacement. J Thorac Cardiovasc Surg 2006;132:32-37.

6. Lansac E, Di Centa I, Raoux F, et al. An expansible aortic ring for a physiological approach to conservative aortic valve surgery. J Thorac Cardiovasc Surg 2009;138:718-724.

7. Lansac E, Di Centa I, Sleilaty G, et al. An aortic ring: from physiologic reconstruction of the root to a standardized approach for aortic valve repair. J Thorac Cardiovasc Surg 2010;140(6 Suppl):S28-35; discussion S45-51. 